\title{
Effects of projected climate change on the glacier and runoff generation in the Naryn River Basin, Central Asia
}

\author{
Rong Gan ${ }^{\mathrm{a}, \mathrm{b}}$, Yi Luo ${ }^{\mathrm{b}, *}$, Qiting Zuo ${ }^{\mathrm{a}}$, Lin Sun ${ }^{\mathrm{b}}$ \\ ${ }^{a}$ School of Water Conservancy \& Environment, Zhengzhou University, 450001 Zhengzhou, China \\ ${ }^{\mathrm{b}}$ Key Laboratory of Ecosystem Network Observation and Modeling, Institute of Geographic Sciences and Natural Resources Research, Chinese Academy of Sciences, 100101 \\ Beijing, China
}

\section{A R T I C L E I N F O}

\section{Article history:}

Received 26 November 2014

Received in revised form 23 January 2015

Accepted 23 January 2015

Available online 3 February 2015

This manuscript was handled by

Konstantine P. Georgakakos, Editor-in-Chief,

with the assistance of Daqing Yang,

Associate Editor

\section{Keywords:}

SWAT model

Latest ensemble of climate models

Climate change

Glacier

Hydrology

\begin{abstract}
S U M M A R Y
Climate change is a major environmental concern and the melting processes of the glaciers and snowpacks are sensitive to climate change. The ultimate effect of the future changes on the glacier and hydrology is unclear and poorly investigated for Central Asia. Here, we use results from the latest ensemble of climate models in combination with a glacier-enhanced Soil Water Assessment Tool (SWAT) hydrologic model to assess the hydrological impact of climate change in the Naryn River Basin, Central Asia. Results indicate that small glaciers suffer from larger relative area losses than large glaciers. Only $8 \%$ of the originally glaciated area for small glaciers will retain glaciers by 2100 for RCP8.5. The rate of area retreat for small glaciers (with an area $<1 \mathrm{~km}^{2}$ ) will slow down for the period 2066-2095, while the glacier area shrinkage is projected to accelerate for large glaciers throughout the twenty-first century. In all cases, glaciers will recede but net glacier melt runoff will reach peak in about 2040. Decreases in future runoff are projected in combination with a negative change in precipitation, snowmelt and higher evapotranspiration. Glacier melt is mainly derived by future temperature changes, while the runoff and snowmelt component are determined by future precipitation. The timing of peak runoff is advancing about one month as a result of earlier snowmelt due to the warming temperature. Runoff is projected to increase during the spring and decrease for the summer season for the future periods. Thus water availability on the time will likely undergo significant changes.
\end{abstract}

(c) 2015 Elsevier B.V. All rights reserved.

\section{Introduction}

Climate change is emerging as the single most important environmental issue of the 21st century (Campbell et al., 2011; Carter et al., 2015). Global air temperatures have increased by $0.85^{\circ} \mathrm{C}$ during the period 1880-2012 (IPCC5, 2013). Precipitation is also changing in volume, intensity, and form (e.g., rain and snow) throughout many regions of the world (Campbell et al., 2011). Most studies agreed on general warming trends in Central Asia with acceleration since the 1970 s, but varied with regard to seasonal changes and the magnitude of the warming (UngerShayesteh et al., 2013a). The temperature projections for RCP4.5 (representative concentration pathways) reveal a region-wide warming of close to $2{ }^{\circ} \mathrm{C}$ (2021-2050 relative to 1961-1990) according to the phase five of the Climate Model Intercomparison Project (CMIP5), and the warming trend is further exacerbated

* Corresponding author at: Key Laboratory of Ecosystem Network Observation and Modeling, Institute of Geographic Sciences and Natural Resources Research, CAS, NO. Jia11, Datun Road, Beijing 100101, China. Tel./fax: +86 1064888920.

E-mail address: luoyi@igsnrr.ac.cn (Y. Luo). for RCP8.5 (Immerzeel et al., 2013). Based on global climate model projections, climate change is expected to considerably affect the Central Asian region; it has been identified as a "hot spot" of climate change, where warming is expected to increase above the global average and the impact on water resources is predicted to be serious (Unger-Shayesteh et al., 2013b).

Mountain glaciers are recognized as key indicators for climate change and as important water storages on a seasonal, mid-term and long-term time scale (Hagg et al., 2013). Recent research shows that even small-scale natural climate fluctuations have had large impacts on glaciers over the past 100,000 years. Glaciers in the Tien Shan and the Pamir continue to retreat and to shrink (Khromova et al., 2006; Li et al., 2006). Several studies based on remote sensing have shown that glacier recession in Central Asia was accelerated during the past decades, especially those at the outer ranges of the mountain systems (Liu et al., 2006; Aizen et al., 2007; Bolch, 2007; Narama et al., 2009). For the water cycle of the Central Asian mountains, glacier retreat will still be of crucial importance during the next century. There is a decrease in maximum snow depth and a reduction in snow cover duration under climate change (Barnett et al., 2005). It also shows that hydrologi- 
cal regimes of snow- and glacier-melt driven rivers will be impacted by a warming climate (Schaefer et al., 2006; Immerzeel et al., 2010). The shifts in climate ultimately affect the quantity and seasonal distribution of streamflow, having important implications for global water supplies (Campbell et al., 2011).

Snow and glacial melt are important hydrologic processes in Central Asian region, and changes in climate are expected to seriously affect the melt characteristics. A number of studies have addressed the importance of snow and glacial melt and the potential effects of climate change on hydrology, but these are mostly qualitative (Barnett et al., 2005; Singh and Bengtsson, 2005; Immerzeel et al., 2010). Unger-Shayesteh et al. (2013a) had reviewed about 100 studies on past changes in climate, snow cover, glaciers and runoff in Central Asian headwater catchments, which have been published in the past 20 years, and concluded that there is a need for sound attribution studies linking the observed hydrological changes in individual catchments to particular processes triggered by climatic and cryospheric changes. Runoff in the high mountain areas of Central Asia were a complex response of catchments to changes in climate.

Most studies investigated the glacier area changes in Central Asia consistently showing regionally heterogenous, with stronger glacier area losses at the northern and eastern margins of the mountain system (Li et al., 2006; Narama et al., 2006; Bolch, 2007; Kutuzov and Shahgedanova, 2009). Aizen et al. (2007) thoroughly studied the changes in glacier area and volume between 1943 and 2003 in the Akshiirak massif, which partly drains to the Naryn basin based on topographic maps, SRTM and ASTER data sources. Niederer et al. (2008) reported a glacier retreat of about 28\% between 1963 and 2000 for the rather small Sokoluk catchment located in the Northern Tien Shan. Narama et al. (2006), who documented a rather small glacier area loss of about $8 \%$ for the Western Terskey Alatoo and the period 1971-2002, found that small glaciers with a size of less than $1 \mathrm{~km}^{2}$ are mostly affected by the retreat. Based on the glacier area inventory and ground penetrating radar measurements, Hagg et al. (2013) found that a volume of about $20 \%$ had been lost and the total glacier area decreased by $23.4 \%$ due to increasing summer temperatures over the second half of the 20th century in the Big Naryn catchment, Upper Syrdarya. The assessment of glacier area changes was extended to the entire Naryn basin and clearly indicated strong variation in glacier loss rates across the basin within the 30 -years investigation period. Positive trends in spring and autumn discharge were detected and are likely to be associated with the enhanced snow and glacier melt driven by temperatures in those seasons. However no discharge trends in August - the month with the largest expected glacier melt - were detected from Naryn headwaters (Kriegel et al., 2013).

The ultimate effect of the projected changes on the glacier and regional water cycle is uncertain and poorly investigated for Central Asia. Projections of future hydrological changes are of vital importance for water management in Central Asia. The objective of this research is to investigate how changes in future precipitation and temperature will affect the glacier and snow melt, change the magnitude and timing of the annual hydrograph and cause shifts in the runoff components using the latest climate model ensemble.

\section{Materials and methods}

\subsection{Study area}

The Naryn River is one of the main tributaries of Syrdarya River, which originates in Tien Shan Mountains in Kyrgyzstan and flows towards northern Aral Sea through Tajikistan, Uzbekistan and
Kazakhstan (Fig. 1). The Naryn River is formed at the confluence of the Big and the Small Naryn rivers. It flows into Ferghana Valley, where it merges with Karadarya to form the Syrdarya River (Hagg et al., 2013). The area of the basin covers $58,205 \mathrm{~km}^{2}$, and about $2 \%$ of the basin area is glacierized. The majority of glaciers is concentrated in the eastern part of the basin. Most part of the catchment area is located mainly in Kyrgyzstan, but small parts of it belong to Uzbekistan.

The Naryn River Basin has a continental climate with dry and hot summer and cold winter. The average temperature is $10^{\circ} \mathrm{C}$ in July, $-18^{\circ} \mathrm{C}$ in January. Annual precipitation ranges between $280 \mathrm{~mm}$ and $450 \mathrm{~mm}$ depending on altitude. The highest share of precipitation falls in spring and early summer (Kriegel et al., 2013). There is the smallest precipitation in summer. Snowfall occurs in winter and takes account of significant parts of precipitation in the mountainous area due to abundant precipitation and low temperature. The maximum runoff occurs in June when the snow in the mountains melts and contributes to river flow. Snow melt contributes a remarkable portion of streamflow. Glacier melt particularly supplies the river in summer.

\subsection{The glacier-enhanced SWAT model}

Soil Water Assessment Tool (SWAT, Arnold and Fohrer, 2005) is a continuous time, distributed watershed model using physically based algorithms designed to simulate most of the hydrological processes. It has been widely used around the world and successfully applied in climatic, land cover and land use, and management practices conditions (Spruill et al., 2000; Chu et al., 2004; Gassman et al., 2007; Liu et al., 2010; Ficklin et al., 2013).

The SWAT model delineates a basin into a number of subbasins. Heterogeneities exist within a subbasin with respect to soil and land use and land cover. To resolve these heterogeneities, a practical alternative is to represent the effects of these heterogeneities statistically by use of the hydrologic response unit (HRU) (Leavesley et al., 1983). The HRUs are lumped land areas within the subbasin that are comprised of unique land cover, soil, and slope. Hydrologic simulation is first performed with regard to each HRU, and then routed through the tributary of each subbasin and the main channel of the basin to the outlet.

SWAT simulates the entire hydrologic processes within a HRU included plant growth, energy balance, soil evaporation and plant transpiration, water body evaporation, snow pack and snow melt, runoff generation and infiltration. Snow pack depletion is accounted for by using the depletion curves. Snow melt is estimated using the conventional temperature-index or degree-day approach (Neitsch et al., 2005). Baseflow was simulated by a linear two-reservoir approach (Luo et al., 2012; Gan and Luo, 2013). However, glacier processes are not presently available. Luo et al. (2013) developed a glacier hydrology module and incorporated it into the code of SWAT 2005 to simulate glacier hydrology in alpine catchments.

The glacier module takes a single glacier as a HRU. Each glacier HRU is divided into elevation bands. Mass balance of glacier HRU is simulated by calculating mass accumulation, melt and evaporation within each band. A degree day approach is used to calculate the glacier melt. The glacier mass balance is calculated on basis of that of the bands. A volume-area scaling relation is used to derive the area change of the glacier. The runoff generated from glacier melt is routed through the tributaries and channel to the catchment outlet. Detailed description to the glacier-enhanced model can be found in Luo et al. (2013). However, there is a lack that an increase in number of glaciers due to disintegration of large compound valley glaciers into a number of simple valley and cirque glaciers is not considered in this simulation. 


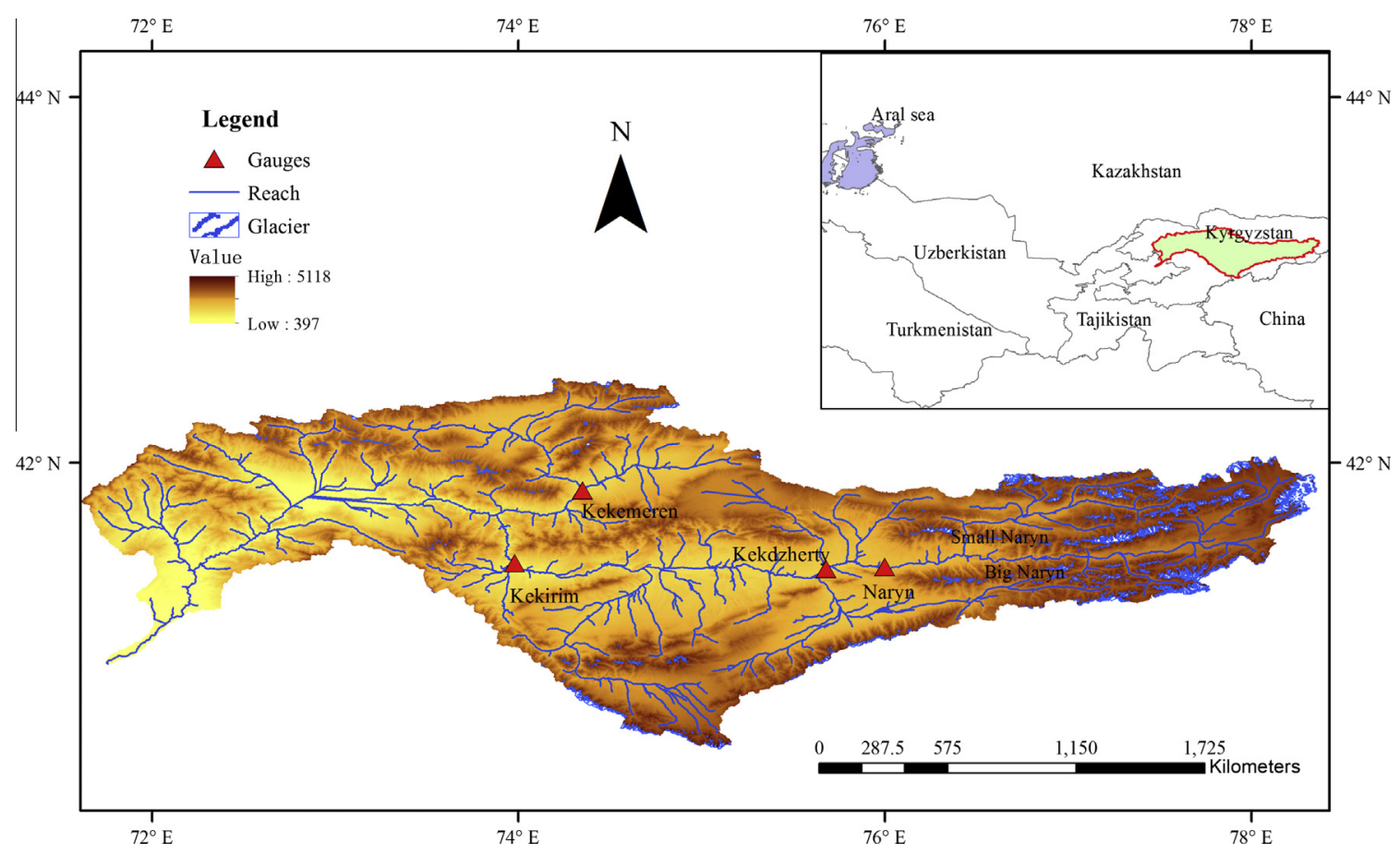

Fig. 1. Location of Naryn catchment and the distribution of glacier.

\subsection{Data preparation}

\subsubsection{Digital elevation model}

Digital Elevation Model (DEM) with grid sizes of $90 \times 90 \mathrm{~m}^{2}$ was obtained from the CGIAR Consortium for Spatial Information (CGIAR-CSI). Digital topographic data were used to delineate the watersheds into subbasins, generate the river networks, and define the water bodies and outlets.

\subsubsection{Soils}

Soil characteristics are derived from the Harmonized World Soil Database (HWSD) of Food and Agriculture Organization of the United Nations, with spatial resolution of about 1000 m (30 arc seconds by 30 arc seconds). Over 16,000 different soil mapping units are recognized in the HWSD, which are linked to harmonized attribute data. Use of a standardized structure allows linkage of the attribute data with GIS to display or query the composition in terms of soil units and the characterization of selected soil parameters (FAO, 2012). At a result, 18 different soil profiles were classified in this study.

The HWSD provides some soil parameters that SWAT can use directly, such as organic Carbon, water storage capacity, salinity, and textural class. Some important parameters such as Available Water Capacity (AWC) and Saturated Hydraulic Conductivity of soils were calculated by the soil information of sand, silt, and clay percentages provided by the HWSD.

\subsubsection{Land cover and glacier}

Land cover characteristics are extracted from the MERIS Globcover product (http://due.esrin.esa.int/globcover/). The land cover was based on the latest version of the world satellite maps in 2009 of European Space Agency, with spatial resolution of $300 \mathrm{~m} \times 300 \mathrm{~m}$. In the study, land cover information was reclassified by combined with Central Asia Glacier Inventory using Arcgis.

Glacier data in the Naryn River was synthesized from the Tien Shan Glaciers V.1 (TSG V.1) (http://www.asiacryoweb.org) and the World Glacier Inventory (WGI) (http://nsidc.org/data/glacier_ inventory/index.html). The TSG V.1 includes two inventories: the time period of 1970s (hereafter, TSG V.1-1970s) and for 2000s (hereafter, TSG V.1-2000s). The glacier property, such as area, minimum, maximum and mean elevation, as well as hypsometry information for each glacier were provided in the database, and the percentage of area change for glaciers covered in both inventories can be obtained.

The WGI is based primarily on aerial photographs and maps with most glaciers having one data entry only. Hence, the data set can be viewed as a snapshot of the glacier distribution in the second half of the 20th century. It is based on the original WGI (WGMS 1989) from the World Glacier Monitoring Service (WGMS). The WGI parameters include geographic location, area, length, orientation, elevation, and classification. This study used the WGI 2012 update.

In this study, the 1970s inventories of TSG V.1 were compared to WGI datasets. Information of Glaciers in the WGI but not covered in the TSG V.1 was retrieved and synthesized with the TSG V.1 to form the new glacier datasets. The areal distribution over elevation for glaciers of the WGI used the area-elevation relationship derived statistically from the TSG V.1 datasets. As a result, statistics of glaciers in the study was shown in Table 1.

A total of 1528 glaciers with an area of $1186 \mathrm{~km}^{2}$ have been identified, corresponding to a glacierization of $2 \%$. The majority of glaciers (84\%) is smaller than $1 \mathrm{~km}^{2}$. These glaciers contain $35 \%$ of the total glacier area. Percentage of glacier number quickly decrease with increasing size class (Table 1). There are fewer glaciers between 3 and $10 \mathrm{~km}^{2}$ than between 1 and $3 \mathrm{~km}^{2}$, but their total area is higher. Only 8 glaciers $(0.5 \%)$ are larger than $10 \mathrm{~km}^{2}$, but they contribute to $15.3 \%$ of the basins' ice cover. It is a common pattern in all glacier systems, suggesting that glacier systems in all the study basins are structured in a similar way, which is that small glaciers dominate in numbers, but, in total, their share in the entire glacier-covered area is small and they contain a tiny fraction of the basin's ice reserves (Savoskul and Smakhtin, 2013).

The altitude of glacier ranges from 2880 to $4860 \mathrm{~m}$ a.s.l. with a mean altitude of $4160 \mathrm{~m}$ a.s.l.; above $4200 \mathrm{~m}$ a.s.l., more than half 
Table 1

Distribution of the number of glaciers and glacier-covered area across glacier size classes in the study basin.

\begin{tabular}{|c|c|c|c|c|}
\hline \multirow[t]{2}{*}{ Size class $\left(\mathrm{km}^{2}\right)$} & \multicolumn{2}{|l|}{ Glacier numbers } & \multicolumn{2}{|l|}{ Glacier area } \\
\hline & Number of glaciers & Share in basin (\%) & Area $\left(\mathrm{km}^{2}\right)$ & Share in basin (\%) \\
\hline$<0.33$ & 725 & 47.6 & 120 & 10.1 \\
\hline $0.33-1$ & 559 & 36.6 & 292.2 & 24.6 \\
\hline $1-3$ & 171 & 11.2 & 280.9 & 23.7 \\
\hline $3-10$ & 63 & 4.1 & 311.6 & 26.3 \\
\hline $10-30$ & 6 & 0.39 & 74.8 & 6.3 \\
\hline $30-100$ & 2 & 0.13 & 106.6 & 9.0 \\
\hline Sum & 1528 & 100 & 1186 & 100 \\
\hline
\end{tabular}

of the catchment is glaciated. The largest areas can be found between 4200 and $4400 \mathrm{~m}$ a.s.l. (Fig. 2). The altitude of catchment area ranges from 388 to $5118 \mathrm{~m}$ a.s.l. with a mean altitude of $2738 \mathrm{~m}$ a.s.l., and are mainly situated on elevations between 3000 and $4000 \mathrm{~m}$ a.s.l., accounting for $48.6 \%$.

Based on the maps of DEM, land covers and Central Asia Glacier inventory and soils, eventually, there were 551subbasins and 3864 HRUs for Naryn River basin and the glacier HRUs were 1528.

\subsubsection{Streamflow and meteorological data}

Streamflow data from four gauges in the Naryn Basin (Fig. 1) were collected from http://webworld.unesco.org/water. Monthly discharge from 1951 to 1985 was used to parameterize and validate simulation due to the daily streamflow were not available.

The long-term pattern of precipitation and temperature in this region is not well known due to a lack of long-term observations, especially in high elevation zone. The complex terrain can introduce significant differences in climate. However, we use available a lengthy daily gridded high-resolution data set: the Asian Precipitation Highly-Resolved Observational Data Integration Towards Evaluation of Water Resources (APHRODITE, Yatagai et al., 2012) dataset for precipitation and Princeton's Global Meteorological Forcing Dataset (PGMFD, Sheffield et al., 2006) for temperature.

APHRODITE is a long-term continental-scale daily precipitation product based on a dense network of rain gauges from thousands of stations across Asia, with a spatial resolution of $0.25^{\circ}$ and a time span from 1957 to 2007, which covers the study area. The PGMFD was constructed by combining a suite of global observation-based datasets with the National Centers for Environmental PredictionNational Center for Atmospheric Research (NCEP-NCAR) reanalysis.

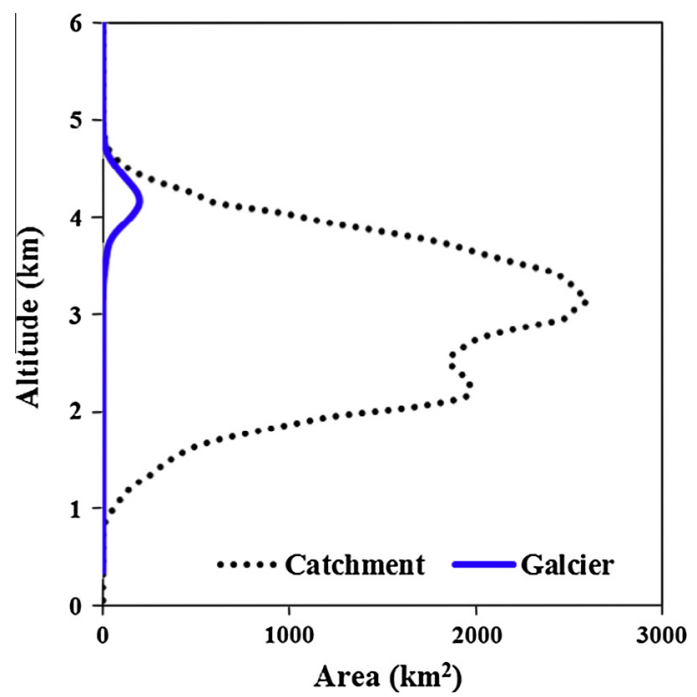

Fig. 2. Distribution of catchment area and glacier area by altitude.
The PGMFD has a spatial resolution of $0.5^{\circ}$ and with a time span from 1948 to 2008. Daily temperature data are bilinearly interpolated to $0.25^{\circ}$ resolution from the PGMFD $0.5^{\circ}$ gridded temperature dataset, which is subsequently consistent with precipitation data.

Vertical lapse rates are important characteristics of climatic variables in mountainous meteorology. The vertical temperature lapse rate (Tlapse) is largely dependent on the moisture content of the air and tends to decrease with elevation as the air gets dryer with altitude generally varies between $-9.8{ }^{\circ} \mathrm{C} \mathrm{km}^{-1}$ and $-5^{\circ} \mathrm{C} \mathrm{km}^{-1}$ (Tahir et al., 2011; Lutz et al., 2014). An underestimate in precipitation may lead to problems in model calibration, for example, underestimation of precipitation may be compensated by an overestimation of glacier melt. We use a single precipitation multiplication factor subject to calibration for each glacier in order to avoid correcting for this with wrong melt parameters. The Tlapse and Plapse (precipitation lapse rate with altitude) for the input of SWAT model were derived from the daily gridded data. Each subbasin was divided into ten bands with equal elevation increment for calculating the temperature and precipitation, also simulating the snow and glaciers.

\subsubsection{Climate change projections and downscaling}

We use the latest climate model ensemble generated for the fifth assessment report of the Intergovernmental Panel on Climate Change (IPCC) by the fifth phase of the Climate Model Intercomparison Project (CMIP5) (Taylor et al., 2012) as future climate forcing. In order to decrease the uncertainty of single model, five global climate models (GCM) participating in CMIP5 were used, which were evaluated as the relative good simulation compared with 38 GCMs in northwest China, Central Asia. These models are listed in Table 2. The simulations cover the period from the mid-19th century to 2005 (historical run) and from 2006 to 2100 with proposed changes in greenhouse gases and anthropogenic aerosols following the IPCC Representative Concentration Pathways 2.6 (RCP2.6), 4.5 (RCP4.5) and 8.5 (RCP8.5). RCP2.6 is missing for CCSM4 model. The RCP2.6 is a strong mitigation scenario and extended by assuming constant emissions, which is the lowest scenario. The RCP4.5 is a stabilization scenario where total radiative forcing is stabilized before 2100 by employing technologies and strategies to reduce greenhouse gas emissions. The RCP8.5 is a business as usual scenario and characterized by increasing greenhouse gas emissions and high greenhouse gas concentration levels.

Downscaling of the GCMs outputs is necessary due to the large scale discrepancy between the climate models. Subsequently we apply the "delta change" approach to generate time series of future air temperature and precipitation. Based on the gridded meteorological dataset of $0.25^{\circ}$ resolution (1950-2005), we found the nearest point from the GCM grid cells and compute a transient "delta change" value. This is done for each selected model and each month that can reflect the seasonal differences in the GCM output. We superimpose the monthly temperature and precipitation 
Table 2

A brief overview of the climate models used in this study.

\begin{tabular}{|c|c|c|c|}
\hline \multirow[t]{2}{*}{ Model } & \multirow[t]{2}{*}{ Origin } & \multicolumn{2}{|c|}{ Resolution } \\
\hline & & Lat. & Long. \\
\hline CCSM4 & National Center for Atmospheric Research, USA & 0.94 & 1.25 \\
\hline CMCC-CM & Euro-Mediterranean Centre for Climate Change, Italy & 0.748 & 0.75 \\
\hline CNRM-CM5 & Centre National de Recherches Meteorologiques, France & 1.40 & 1.40 \\
\hline IPSL-CM5A-LR & Institut Pierre-Simon Laplace, France & 1.875 & 3.75 \\
\hline MPI-ESM-LR & Max Planck Institute for Meteorology, Germany & 1.875 & 1.875 \\
\hline
\end{tabular}

change grids to construct a transient time series from 2006 to 2100 .

\subsection{Model parameterization and calibration procedure}

The processes of parameters calibration follow the criterion: first the upstream then downstream; first the water balance then the hydrological process. The degree-day factor for snow/ice melt is calculated by a sinusoidal function to represent its seasonal change pattern with maximum and minimum values occurring on summer and winter solstices (Neitsch et al., 2005; Luo et al., 2013). The ranges of the glacier melt degree-day factors were determined according to the mention by Li et al. (2012). The initial melt factors for the maximum and minimum values were assigned to each glacier hydrologic response unit, and were calibrated based on the glacier mass balance and the glacier area changes in the region. Glacier area changes come from the starting glacier inventory (TSG V.1-1970s) and endpoint (TSG V.1-2000s). The degreeday factors for snowmelt were calibrated based on the seasonal distribution and the magnitude of simulated streamflow. The streamflow was calibrated in monthly scale since daily observed discharge was not available for the study. Nash-Sutcliffe efficient (NSE), the Percent Bias (PBIAS) and coefficient of determination $\left(R^{2}\right)$ were used as statistical indices to assess the goodness of fit of the model (Moriasi et al., 2007).

$$
\mathrm{NSE}=1-\frac{\sum_{1}^{n}\left(Q_{i}^{\mathrm{obs}}-Q_{i}^{\text {sim }}\right)^{2}}{\sum_{i}^{n}\left(Q_{i}^{\text {obs }}-Q^{\text {mean }}\right)^{2}}
$$

PBIAS $=\frac{\sum\left(Q_{i}^{\text {obs }}-Q_{i}^{\text {sim }}\right) * 100}{\sum Q_{i}^{\text {obs }}}$

$R^{2}=\frac{\left(n \sum Q_{i}^{\mathrm{obs}} Q_{i}^{\mathrm{sim}}-\sum Q_{i}^{\mathrm{obs}} \sum Q_{i}^{\mathrm{sim}}\right)^{2}}{\left[n \sum\left(Q_{i}^{\mathrm{obs}}\right)^{2}-\left(\sum Q_{i}^{\mathrm{obs}}\right)^{2}\right]\left[n \sum\left(Q_{i}^{\mathrm{sim}}\right)^{2}-\left(\sum Q_{i}^{\text {sim }}\right)^{2}\right]}$

where $Q_{i}^{\text {obs }}$ is the observed streamflow, $Q_{i}^{\text {sim }}$ is the streamflow simulated by model.

NSE indicates how well the plot of observed versus simulated data fits the 1:1 line. A value of 1.0 represents a "perfect" prediction, while a value of 0.0 suggests that the model predictions are no more accurate than predicting the mean of observed values. A NSE $>0.5$ is satisfactory suggested by Moriasi et al. (2007). PBIAS measures the average tendency of the simulated data to be larger or smaller than their observed counterparts. The optimal value of PBIAS is 0.0 , with low-magnitude values indicating accurate model simulation. Positive values indicate model underestimation bias, and negative values indicate model overestimation bias. $R^{2}$ describes the proportion of the variance in measured data explained by the model. $R^{2}$ ranges from 0 to 1 , with higher values indicating less error variance, and typically values greater than 0.5 are considered acceptable (Moriasi et al., 2007).

The period from 1951 to 1975 was used to calibrate the SWAT model for streamflow with the first five-year as a warm up period using the observed station data. The validation of the model was carried out for the period 1976 to 1985 . Besides validation to observed discharge, the average contribution of glacier melt and the area losses are compared to findings in this region.

\section{Results and discussion}

\subsection{Parameterization and performance evaluation}

The optimal parameters for the snow and glacier melt are listed in Table 3. The results of the calibration and validation of the model for the four stations are listed in Table 4. For the four locations the average NSE for model efficiency equaled 0.81 , the average PBIAS was -9.23 and the $R^{2}$ was 0.79 . It indicated that the simulation yielded "very good" results following the rating rules given by Moriasi et al. (2007). The values of PBIAS are smaller than \pm 10 except for the Keririm station, which is in downstream of Naryn River. This might be due to the effect of human activities (Long et al., 2012), which were not considered in this study.

Fig. 3 presents the comparison of streamflow among those observed and simulated for Naryn River basin. During the simulation periods the monthly streamflow simulated by SWAT-RSG model show a similar trend to those observed. During the validation periods, it is noticed that the simulated annual runoffs are slightly smaller than those observed at the Naryn station in the upstream of Naryn River, while it gives a serious overestimation of runoff at the Kekirim station in the downstream of Naryn River. It indicates that anthropogenic water withdrawals, mostly for irrigation purposes have an impact on the volume. There are significant differences between the simulated and the measured maximum flow volume. The difference might be due to the uncertainty of meteorological input in mountain areas.

An analysis between streamflows simulated using observed climate data and streamflows using historical GCM projections was conducted to determine if there was a bias in the GCM projections. Average annual hydrographs of streamflow using observed climate data and historical GCM projections for 1966-1995 were showed in Fig. 4. Very little bias was found between the two historical streamflow sets. The PBIAS between streamflow using observed climate and streamflow using historical GCM projections was -5.34 . The mean daily flow rate was $433 \mathrm{~m}^{3} \mathrm{~s}^{-1}$ and the volume of $136.5 \times 10^{8} \mathrm{~m}^{3}$ by observed climate data during the baseline period, while the simulated value was $437 \mathrm{~m}^{3} \mathrm{~s}^{-1}$ and the volume of $137.8 \times 10^{8} \mathrm{~m}^{3}$ for the same period. We therefore have confidence that the historical simulations derived from GCM historical projections are reasonable as compared to the results by observed climate data.

We also validate the method based on the change of glaciers. We use two glacier inventories, making the starting point (TSG V.1-1970s) and endpoint (TSG V.1-2000s) to derive the area change of glaciers for the model validation. The observed decrease in glacier area according to the two glacier inventories equals $7.3 \%$ from 1973 to 2002, and the simulated glacier area losses is $7.5 \%$ for the same period. The glacier melt had a share of $7.3-9.2 \%$ in total run- 
Table 3

The calibrated parameter values for the investigated catchments.

\begin{tabular}{|c|c|c|c|}
\hline Parameters & Definitions & Units & Value \\
\hline$b_{\text {gmltt, } 6}$ & Glacier melt degree-day factor on June 21 & $\mathrm{~mm}^{\circ} \mathrm{C}^{-1} \mathrm{~d}^{-1}$ & $2-11$ \\
\hline$b_{\text {gmlt, } 12}$ & Glacier melt degree-day factor on December 21 & $\mathrm{~mm}^{\circ} \mathrm{C}^{-1} \mathrm{~d}^{-1}$ & $1-5.5$ \\
\hline SMFMX & Snow melt degree-day factor on June 21 & $\mathrm{~mm}^{\circ} \mathrm{C}^{-1} \mathrm{~d}^{-1}$ & $1-6$ \\
\hline SMFMN & Snow melt degree-day factor on December 21 & $\mathrm{~mm}^{\circ} \mathrm{C}^{-1} \mathrm{~d}^{-1}$ & $1-3.5$ \\
\hline SFTMP & Snowfall temperature & ${ }^{\circ} \mathrm{C}$ & 1.0 \\
\hline SMTMP & Snow melt base temperature & ${ }^{\circ} \mathrm{C}$ & 1.5 \\
\hline GW_DELAY & Delay time for aquifer recharge & days & 45 \\
\hline ALPHA_BF & Baseflow recession constant of shallow aquifer & & 0.15 \\
\hline ALPHA_BF_DP & Baseflow recession constant of deep aquifer & & 0.02 \\
\hline
\end{tabular}

Table 4

Statistical indices for assessing performance of the simulation.

\begin{tabular}{|c|c|c|c|c|c|c|c|c|c|}
\hline \multirow[t]{2}{*}{ Station } & \multicolumn{3}{|c|}{ Overall } & \multicolumn{3}{|c|}{ Calibration } & \multicolumn{3}{|c|}{ Validation } \\
\hline & NSE & PBIAS & $R^{2}$ & NSE & PBIAS & $R^{2}$ & NSE & PBIAS & $R^{2}$ \\
\hline Naryn & 0.80 & -2.97 & 0.81 & 0.79 & -6.18 & 0.81 & 0.83 & 4.75 & 0.84 \\
\hline Kekdzherty & 0.83 & -2.96 & 0.83 & 0.82 & -6.49 & 0.83 & 0.86 & 5.29 & 0.86 \\
\hline Kekirim & 0.76 & -25.42 & 0.82 & 0.73 & -23.66 & 0.82 & 0.82 & -30 & 0.85 \\
\hline Kekemeren & 0.86 & -5.76 & 0.68 & 0.85 & -3.55 & 0.67 & 0.89 & -11.56 & 0.76 \\
\hline
\end{tabular}

off volume between 1956 and 2007 in the big Naryn River (Hagg et al., 2013), and 7.8\% in the Naryn River (Sorg et al., 2012), where in this study $6 \%$ was found. It shows that our estimates of melt water contribution are somewhat lower than other results, which may be due to the differences in time period, scales, and approach. Hence, we conclude that the used model is capable of simulating the magnitude and composition of runoff.

\subsection{Projected climate change for the Naryn River Basin}

Table 5 shows projected changes in average annual temperature and precipitation for each RCP for two future time periods: the near future (2016-2045) and the end of the century (2066-2095) relative to the baseline period (1966-1995). As time passes, the temperature is projected to rise by $1.73{ }^{\circ} \mathrm{C}$ to more than $5^{\circ} \mathrm{C}$. For RCP2.6, the temperature change for 2016-2045 and 2066-2095 periods is 1.73 and $1.82^{\circ} \mathrm{C}$, respectively. For RCP4.5, the temperature change for $2016-$ 2045 and $2066-2095$ periods is 1.79 and $3.12{ }^{\circ} \mathrm{C}$, respectively. While for RCP8.5, the temperature change is 2.05 and $5.43^{\circ} \mathrm{C}$, respectively. There is significant increase for each RCP.

Precipitation projections are uncertain, in general, there will be a slight downward trend. For RCP2.6, the precipitation change for 2016-2045 and 2066-2095 periods relative to the baseline period (1966-1995) is $-2.85 \%$ and $2.34 \%$, respectively. For RCP4.5, the change for 2016-2045 and 2066-2095 periods is $-1.53 \%$ and $-0.33 \%$, respectively. While for RCP8.5, the precipitation change is -1.1 and $-7.43 \%$.

Projected changes in annual hydrographs of temperature and precipitation for each RCP for two future periods are presented in Fig. 5. The temperature differences of three scenarios for the period 2016-2045 are small, with roughly the same magnitude throughout the year regardless of the cold season or warm season. For the period 2066-2095, the temperature differences for three RCPs are obvious, but temperature increases were distributed fairly evenly over the year. Projected changes in precipitation are small and uneven. Winter and spring precipitation are projected to increase in the future two periods, while summer and autumn precipitation decrease.

\subsection{Implications of climate change for glacier area}

Each glacier area can by simulated and output directly from the model at the daily scale. The glacier area on the last day of the year is taken as the area of the given year. The glacier area changes for different periods were calculated by subtracting the endpoint area from the area of the starting year for the period. The total glacier area will likely shrink from the initial $1186 \mathrm{~km}^{2}$ to $759 \mathrm{~km}^{2}$, $613 \mathrm{~km}^{2}$ and $415 \mathrm{~km}^{2}$ in 2100 for the RCP2.6, RCP4.5 and RCP8.5, respectively. The projected area changes of different glacier size relative to the starting point for the year 1960 are listed in Table 6. The vast change of glacier area is small glaciers. The glacier area of big glaciers $\left(>30 \mathrm{~km}^{2}\right)$ will on average be reduced by $18 \%, 23 \%$ and $32 \%$ by 2100 for the RCP2.6, RCP4.5 and RCP8.5, respectively. While for small glaciers $\left(<0.3 \mathrm{~km}^{2}\right)$, under a strong mitigation scenario (RCP2.6), 42\% of the glaciated area remains ice covered. Under a stabilization scenario (RCP4.5), $24 \%$ of the glaciated area remains ice covered, and under a usual scenario (RCP8.5), only $8 \%$ of the originally glaciated area will retain glaciers by 2100 . Thus, most of small glaciers might disappear. Small glaciers show larger relative area losses than large glaciers. This phenomenon could be explained by the locations of small glaciers, which are often located at lower elevations compared to the large glaciers and are exposed to higher temperatures. In addition, small glaciers have shorter response times. Hence, small glaciers adjust their area faster to mass losses and are thus more sensitive to climate changes (Raper and Braithwaite, 2009; Kriegel et al., 2013; Unger-Shayesteh et al., 2013a).

The shrinkage rates for RCP8.5 are largest than for the other RCPs (RCP2.6 and RCP4.5) with lower temperature for the same sized glaciers. The increase of temperature will accelerate the glacier degradation. The glacier retreat is likely to be driven by the increasing summer temperature, rather than changes in precipitation. However, the rate of glacier recession will slow down in the period 2066-2095 for small glaciers $\left(<1 \mathrm{~km}^{2}\right)$ after the increase in the period 2016-2045, yet it is still higher than the initial recession rate for the baseline period 1966-1995, while the recession rate is projected to increase until 2100 for large glaciers (Table 6). The rate of glacier recession will slow down in the period 2066- 

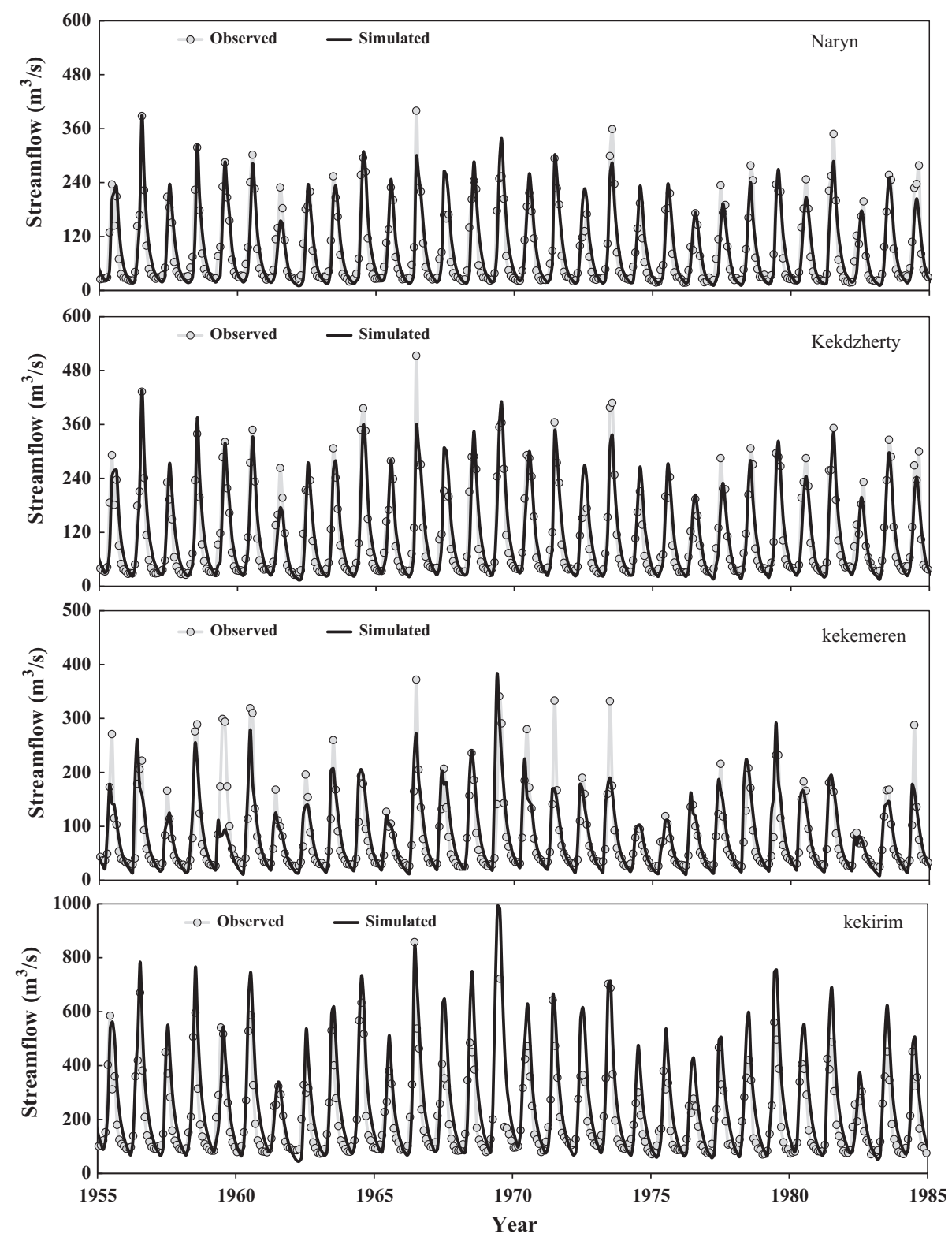

Fig. 3. Observed and simulated streamflow for the calibration and validation periods for Naryn River Basin.

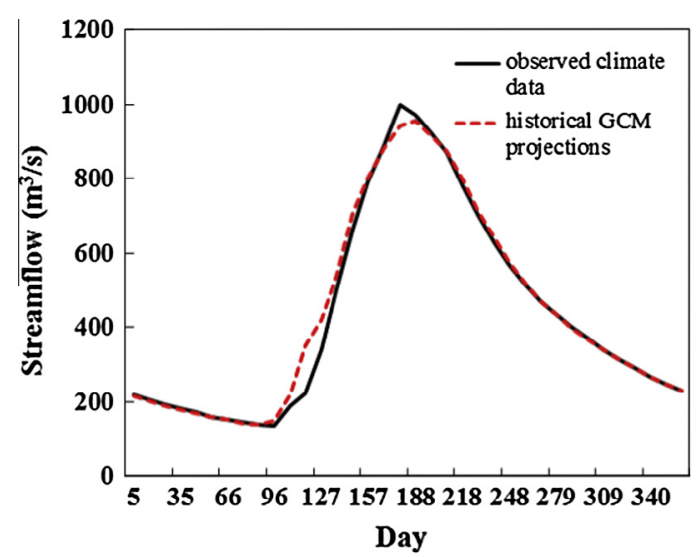

Fig. 4. Average annual hydrographs using observed climate data and historical GCM projections for 1966-1995.
Table 5

Change in the climate for the future periods for three different RCPs relative to 1965 1995. (All values are average for the five GCMs for RCP4.5 and RCP8.5, four GCMs for RCP2.6 and RCP8.5; precipitation is percentage changes and temperature is absolute change.)

\begin{tabular}{|c|c|c|c|c|c|c|}
\hline & \multicolumn{3}{|c|}{ 2016-2045 } & \multicolumn{3}{|c|}{ 2066-2095 } \\
\hline & Rcp2.6 & Rcp4.5 & Rcp8.5 & Rcp2.6 & Rсp4.5 & Rcp8.5 \\
\hline Temperature & 1.73 & 1.79 & 2.05 & 1.82 & 3.12 & 5.43 \\
\hline Precipitation & -2.85 & -1.53 & -1.10 & 2.34 & -0.33 & -7.43 \\
\hline
\end{tabular}

2095 for RCP2.6 for all the glacier size classes due to the relatively stable temperature during this period.

The projected changes in the total glacier area with elevation for each RCP in Naryn River Basin are presented in Fig. 6. The area of low-elevated glaciers exhibits a reduction, whereas the area of high-elevated glaciers remains stable. The largest areas can be found between 4100 and $4200 \mathrm{~m}$ a.s.l. for 1966-1995 period. For 2016-2045, the elevation for the largest areas is projected to be 

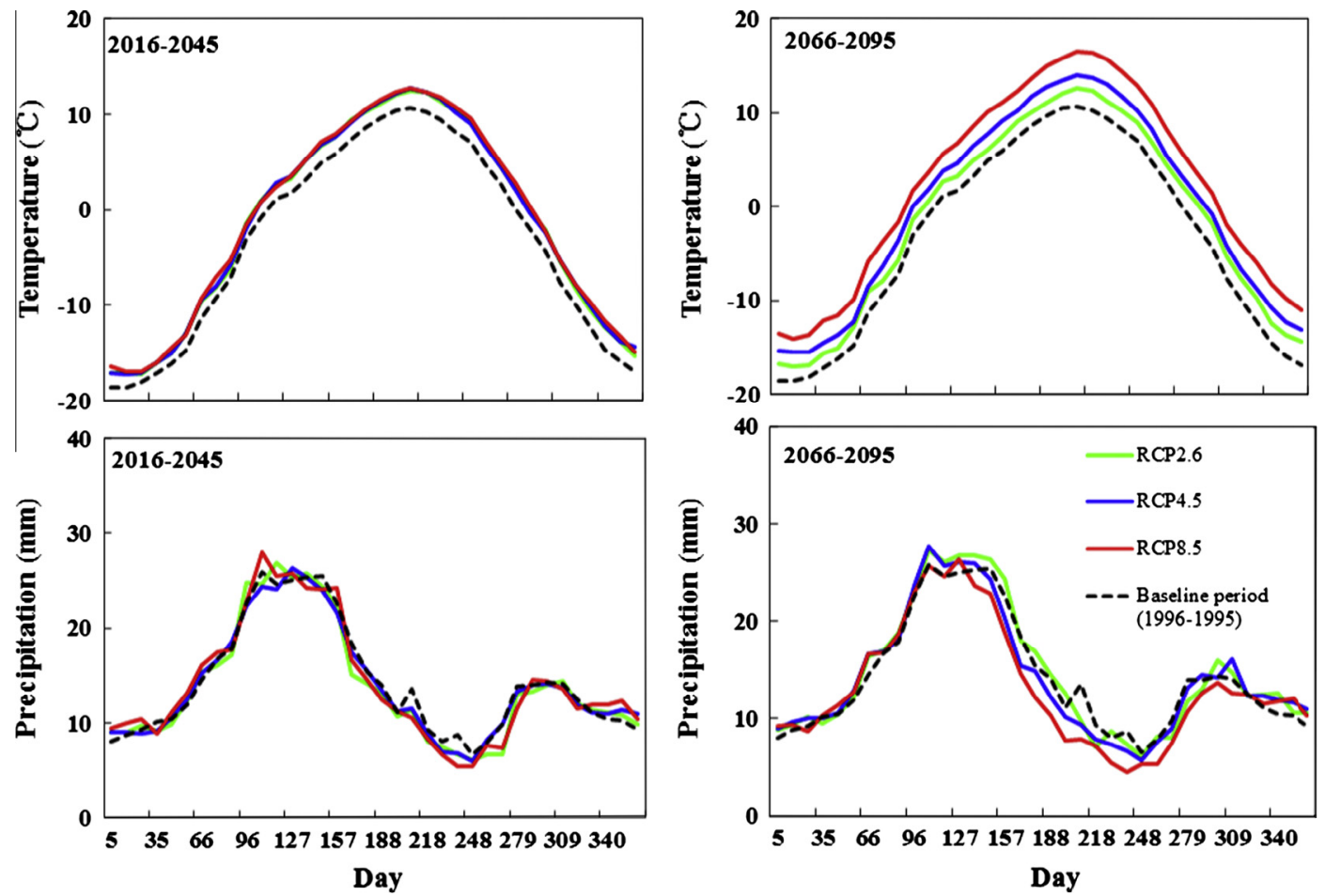

Fig. 5. Comparison of average precipitation and temperature under three different RCP periods relative to baseline period (1966-1995) in Naryn River Basin.

Table 6

Change for glacier area for each RCP for different periods relative to the year 1960 .

\begin{tabular}{|c|c|c|c|c|c|c|c|}
\hline \multirow[b]{2}{*}{ Size class } & \multirow{2}{*}{$\begin{array}{l}\text { Historic } \\
\text { 1966-1995 }\end{array}$} & \multicolumn{2}{|l|}{ RCP2.6 } & \multicolumn{2}{|l|}{ RCP4.5 } & \multicolumn{2}{|l|}{ RCP8.5 } \\
\hline & & $2016-2045$ & 2066-2095 & $2016-2045$ & 2066-2095 & 2016-2045 & 2066-2095 \\
\hline$<0.3$ & 12.6 & 24.7 & 8.7 & 25.9 & 18.5 & 28.9 & 26.1 \\
\hline $0.3-1$ & 10.7 & 18.8 & 9.5 & 19.5 & 18.5 & 21.5 & 29.2 \\
\hline $1-3$ & 8.9 & 13.3 & 8.2 & 13.9 & 15.8 & 15.4 & 27.1 \\
\hline $3-10$ & 8.6 & 10.7 & 7.2 & 11.2 & 13.0 & 12.2 & 22.4 \\
\hline $10-30$ & 6.1 & 8.1 & 5.7 & 8.4 & 10.4 & 9.1 & 18.5 \\
\hline$>30$ & 4.8 & 5.2 & 4.2 & 5.6 & 7.2 & 6.0 & 12.9 \\
\hline
\end{tabular}
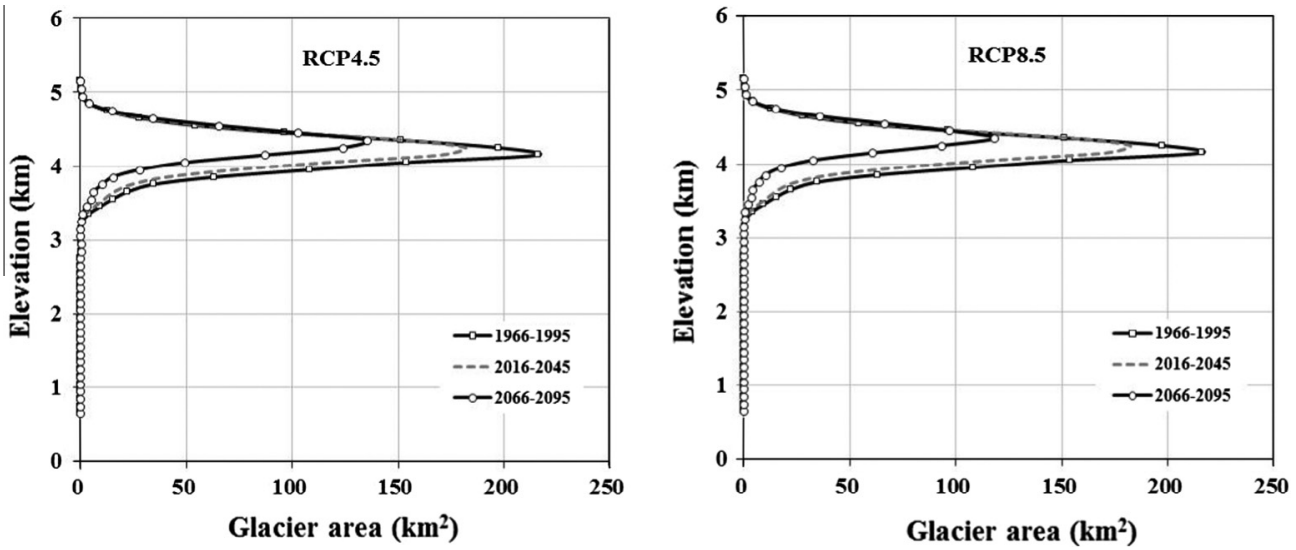

Fig. 6. Projected change of glacier area with altitude for three periods

between 4200 and $4300 \mathrm{~m}$ a.s.l., and for 2066-2095, 4300-4400 m a.s.l. The mean elevation for the glacier will increase.

\subsection{Future hydrology of the Naryn River Basin}

The impact of potential climate change on hydrology derived using the GCMs relative to baseline period (1966-1995) were listed in Table 7. It shows a consistent decrease in total runoff at least until 2100 for RCP2.6, RCP4.5 and RCP8.5. This may be explained by the fact that the precipitation and snowmelt will decrease and the evapotranspiration increase. These decreases range from $4 \%$ to $9.2 \%$ in $2016-2045$ to $1 \%$ to $16.9 \%$ in 2066-2095. The decrease of runoff is projected to accelerate. 
Table 7

Change in the hydrology for 2016-2045 and 2066-2095 for three different RCPs. (All values are percentage changes relative to 1965-1995 and average for the four GCMs for RCP2.6, and five GCMs for RCP4.5 and RCP8.5.)

\begin{tabular}{lrrrrrrr}
\hline & \multicolumn{2}{l}{$2016-2045$} & & & & & \\
\cline { 2 - 3 } & Rcp2.6 & Rcp4.5 & Rcp8.5 & & Rcp2.6 & Rcp4.5 & Rcp8.5 \\
\hline Runoff & -9.22 & -5.42 & -4.01 & & -0.87 & -5.57 & -16.88 \\
Evapotranspiration & 6.31 & 5.96 & 5.69 & & 7.80 & 9.18 & 9.13 \\
Snowmelt & -2.74 & -9.95 & -25.31 & -2.74 & -9.95 & -25.31 \\
Glacier melt & 22.79 & 25.77 & 30.75 & -1.82 & 15.91 & 39.50 \\
Baseflow & -10.16 & -7.72 & -6.29 & -2.15 & -8.01 & -19.79
\end{tabular}

Total annual evapotranspiration is projected to increase under climate change. Under the RCP2.6, evapotranspiration is projected to increase to $6.3 \%$ during the period $2016-2045$ and $7.8 \%$ during the period 2066-2095. Under the RCP4.5 and the RCP8.5, the changes of evapotranspiration are projected to be similar, with increase to about 6\% in 2016-2045 and about 9\% in 2066-2095. Larger increases by the end of the twenty-first century are expected. With a projected decrease in precipitation, increased evapotranspiration may result in a large loss of water. Evapotranspiration exerts a significant control on runoff during the summer, where little to no precipitation occurs.
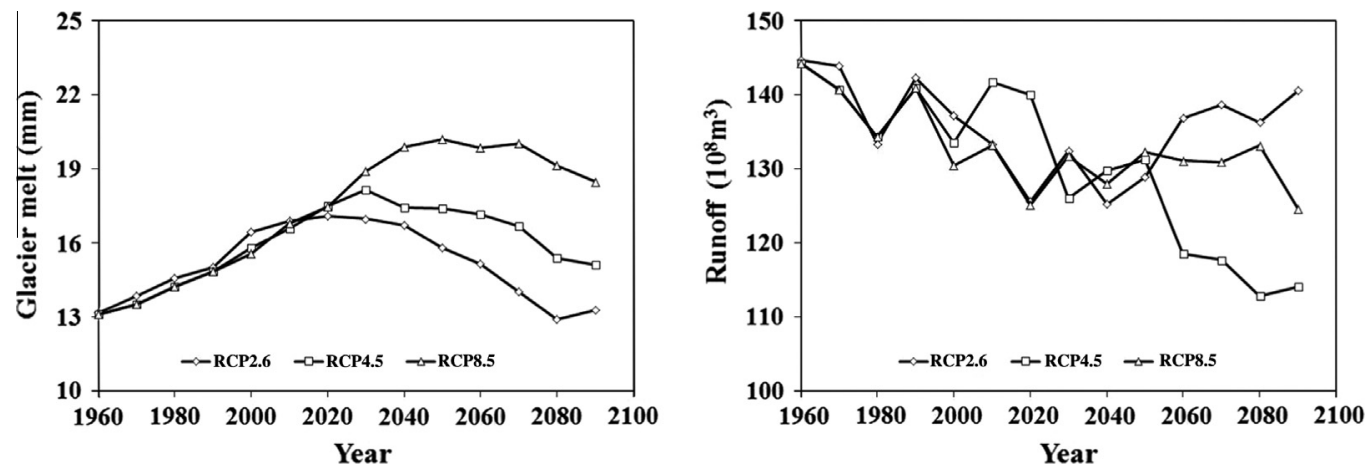

Fig. 7. Projected change of glacier melt and runoff.
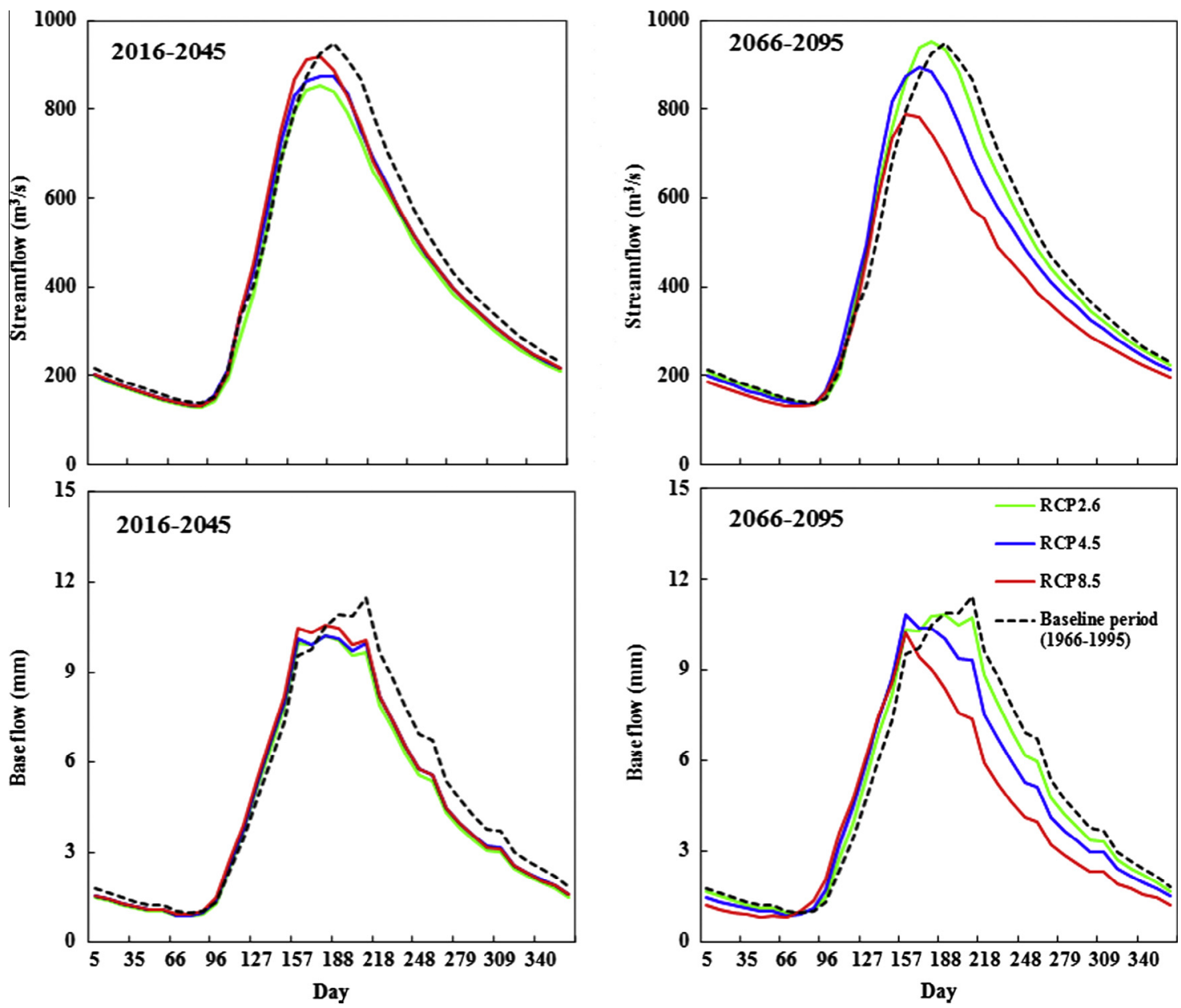

Fig. 8. Comparison of daily average runoff and baseflow simulated under three different RCP periods in Naryn River Basin. 
The future snowmelt decreases for all models in all RCPs, as the increasing temperatures and limited change in precipitation result in a shift towards more liquid precipitation (Lutz et al., 2014). Under the RCP2.6, snowmelt is projected to decrease by $9.2 \%$ during the period 2016-2045 and 2.7\% during the period 2066-2095. Under the high emissions scenario RCP8.5, a decrease of $6.9 \%$ in snowmelt is projected in 2016-2045 and 25.3\% in 2066-2095.

Glacier melt, here defined as the total runoff generated on glaciers, including the melt of snow, firn, ice as well as liquid precipitation on the glacierized areas (Unger-Shayesteh et al., 2013a) is projected to increase except in 2066-2095 for RCP2.6. The average ten-year glacier melt is illustrated in Fig. 7. The amount of glacier melt contributing to the total runoff does not change much in near future because the decrease in glacier area is compensated by an increase in melt rate. The glacier melt will reach the peak time in 2020 for RCP2.6, 2030 for RCP4.5 and 2050 for RCP8.5. An average contribution of glacier melt of $6 \%$ was estimated for 1956-2007, thus glacier melt is not a dominated runoff component in Naryn River Basin. The increase of glacier melt will not cause the increase of total runoff (Fig. 7). Glacier melt is mainly derived by future temperature changes, while the runoff and snowmelt component are determined by future precipitation.

During the period 2016-2045, baseflow could drop by $10.2 \%$ under RCP2.6 scenario and by $6.3 \%$ under RCP8.5 scenario. With increasing scenario, the rate of decrease in baseflow will reduce. During the period 2066-2095, baseflow could decrease on average by $2.2 \%$ under RCP2.6 and by $19.8 \%$ under RCP 8.5 (Table 7 ). Then, with increasing scenario, the rate of decrease in baseflow will increase. The decrease of baseflow may be caused by the decrease of precipitation and snowmelt, which is the main contribution to baseflow using isotopic measurements (Liu et al., 2008; Cable et al., 2011). Baseflow is an important component of total runoff and the decrease in baseflow can cause of the decrease in total runoff. The projected changes of runoff trend are matched with the changes of baseflow.

In addition to changes in annual runoff, runoff timing is shifted as shown in Figs. 8 and 9. For the historical time period, the streamflow peaked in June, whereas, for the 2066-2095, streamflow peaked up to 1 month earlier, resulting in early June or May peak for the RCP2.6 and a May peak for the RCP8.5. The magnitude of the streamflow peak is projected to decrease, which may be due to the decease of the magnitude of the snowmelt at the same period and baseflow peak. For the 2066-2095, peak runoff decreased by $5.7-16.8 \%$ for RCP4.5 and RCP8.5 as compared to historical volumes. Fig. 8 also illustrates that average streamflow is projected to increase during the spring and decrease for the summer season for all time periods and RCPs. Thus water availability on the time will likely undergo significant changes. The winter streamflow will decrease due to the decrease of baseflow, which is the main component of runoff, particularly during low flow periods. The changes of baseflow hydrographs are in agreement with streamflow hydrographs. Spring baseflow will increase and in the other seasons will decrease as well peak time shift. Under various RCPs, spring baseflow in Naryn River Basin is projected to increase by $27-48 \%$ in 2066-2095. The change could be large under RCP8.5.
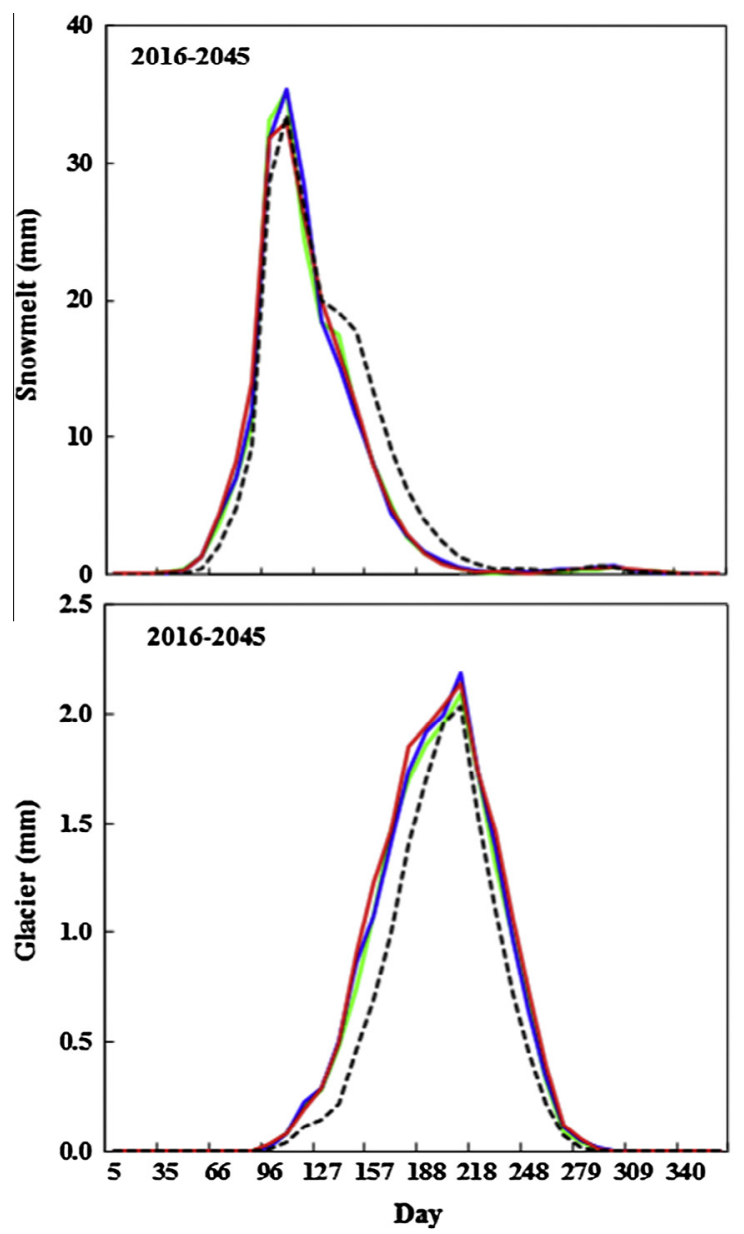
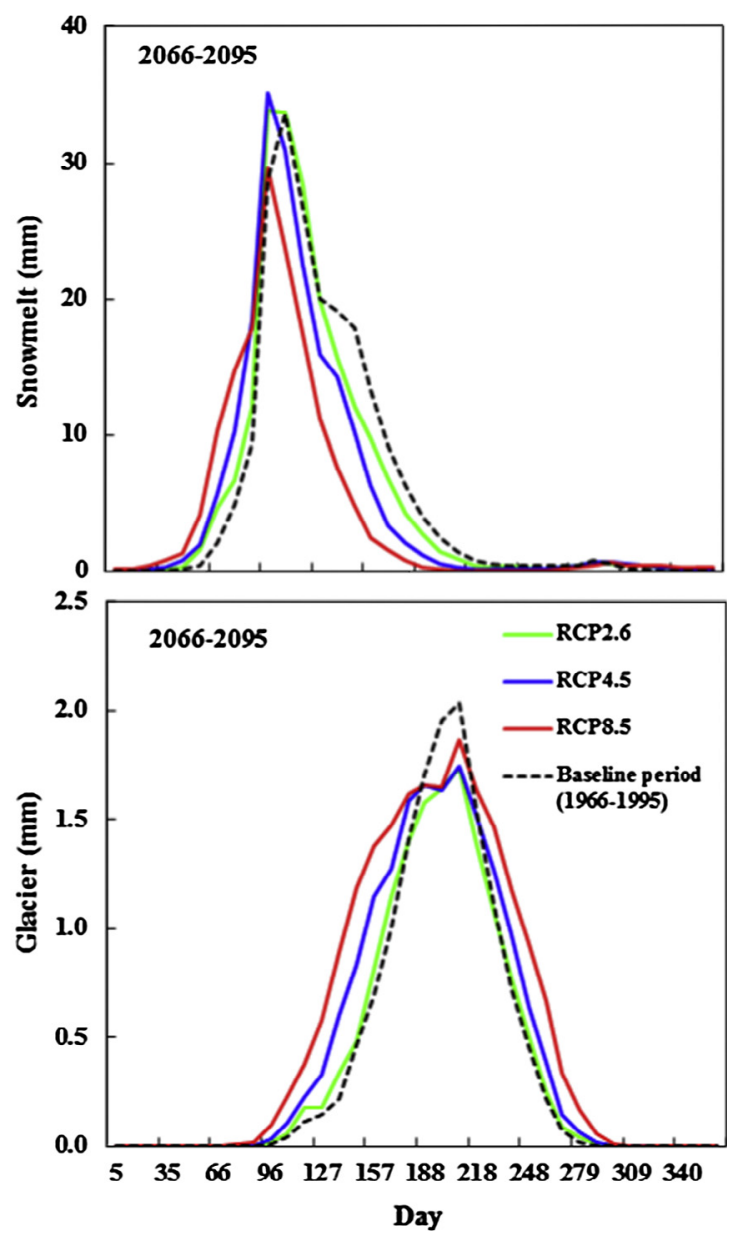

Fig. 9. Average annual hydrographs of snowmelt and glacier melt for the future periods under three different RCPs in Naryn River Basin. 
Projected changes in snowmelt and glacier melt for each RCP for two future periods compared with baseline period are presented in Fig. 9. It shows that snowmelt is projected to occur earlier due to higher temperatures, which results in a larger fraction of precipitation falling as rain rather than snow as well as earlier melt. Despite the smaller fraction of snow, snowmelt will increase in winter and early spring due to the increase of precipitation over the same period. Summer snowmelt is projected to decrease as a result of the earlier melt and the decrease of summer precipitation (Fig. 5). For the 2066-2095, summer snowmelt will decrease by $30 \%, 63 \%$ and $85 \%$ as compared to baseline volumes for RCP2.6, RCP4.5 and RCP8.5, respectively. Snowmelt timing is projected to shift until the end of the century 2066-2095. It reaches its peak in April for the near future (2016-2045) at the same time with the baseline period, whereas, for the 2066-2095, snowmelt peaks up to one month earlier. Further, the magnitude of the snowmelt peak increase except the RCP8.5 for the 2066-2095.

The projected changes in the average annual hydrographs of glacier melt reveal how similar the responses to climate change are between RCPs (Fig. 9). Glacier melt is projected to increase for all seasons for the near future period (2016-2045) owing to the increased temperature leading to accelerated glacier melt. For the 2066-2095, peak melt for all RCPs will decrease but the timing of peak melt will not be shift.

Runoff is recharged by rainfall, snowmelt, glacier melt and baseflow. The changes of these components may result in the shift of runoff timing. Projected precipitation will change in the magnitude but the timing of peak will not be shift. Snowmelt is projected to occur and reach the peak earlier due to higher temperatures. Glacier melt is projected to occur earlier but the peak time will not change. The baseflow is projected to occur and reach the peak earlier due to earlier snowmelt. In the combined effects of these components, the earlier snowmelt may play a more important role in the shift of the peak runoff, while the runoff will decrease as a result of the decreasing precipitation.

\section{Conclusions}

Projections of future hydrological changes are of vital importance for water management in Central Asia. This study presented the impacts of climate change on future runoff generation of snowmelt- and glacier-dominated basin in Central Asia through the 21th century using the latest climate model ensemble under three scenarios (RCP2.6, RCP4.5 and RCP8.5).

Based on the 5 GCM projections in the Naryn River Basin, temperature is projected to appreciably increase relative to baseline period 1966-1995, while overall precipitation will little or no change. Annual average increases in temperature by the end of the century are $1.8,3.1$ and $5.4^{\circ} \mathrm{C}$ for the RCP2.6, RCP4.5 and RCP8.5, respectively. The GCM ensemble predicts an increase in average change in annual precipitation by $2.3 \%$, while a decrease by $0.3 \%$ for RCP4.5 and $7.4 \%$ for RCP 8.5 by the end of the century.

Under the projected climate change, glacier retreat will accelerate through the end of the century and strongly depends on the glacier size distribution. Small glaciers with an initial area of less than $1 \mathrm{~km}^{2}$ experience a stronger area loss than larger glaciers. It indicates that about $58 \%, 76 \%$ and $92 \%$ of area losses for small glacier in 2100 for RCP2.6, RCP4.5 and RCP8.5, respectively. Glacier degradation rates will be stronger in higher temperature scenarios. The mean elevation for the glacier will increase by approximately $200 \mathrm{~m}$ from the baseline period to the period 2066-2095. The area of low-elevated glaciers exhibits a reduction, whereas the area of high-elevated glaciers remains stable.

The results suggest that annual runoff, snowmelt and baseflow will decrease, with the largest declines by the end of the century.
Glacier melt runoff will increase and it is on a rising limb at least until 2040. The decreased runoff can be explained by the decrease in precipitation and higher evapotranspiration. The average annual total runoff is project to decrease by $1 \%, 6 \%$ and $17 \%$ by the end of the 21th century for RCP2.6, RCP4.5 and RCP8.5, respectively. Glacier melt is mainly derived by future temperature changes, while the runoff and snowmelt component are determined by future precipitation.

In addition to reduced overall runoff, warmer temperatures connected to decreased snow deposition and earlier snowmelt are expected to shift the timing of runoff to earlier in the year. Peak runoff in the Naryn River Basin will advance from June to May. It showed that shifts in runoff timing are likely to increase the spring runoff average and decrease the summer average when water usage demand is at its highest, thus further complicating water resource diversions.

\section{Acknowledgements}

This study is supported partially by the Natural Science Foundation of China (Grant No. 41130641), the International Co-operation Program of the Ministry of Science and Technology of China (No. 2010DFA92720), the Project of the National Eleventh-Five Year Research Program of China (2012BAC19B07) and the Natural Science Foundation of China (No. 51279183). Thanks to the editor and the anonymous reviewers for their insightful comments and suggestions.

\section{References}

Aizen, V.B., Kuzmichenok, V.A., Surazakov, A.B., Aizen, E.M., 2007. Glacier changes in the Tien Shan as determined from topographic and remotely sensed data. Global Planet. Change 56, 328-340.

Arnold, J.G., Fohrer, N., 2005. SWAT2000: current capabilities and research opportunities in applied watershed modeling. Hydrol. Process. 19 (3), 563-572.

Barnett, T.P., Adam, J.C., Lettenmaier, D.P., 2005. Potential impacts of a warming climate on water availability in snow-dominated regions. Nature 438, 303-309.

Bolch, T., 2007. Climate change and glacier retreat in northern Tien Shan (Kazakhstan/Kyrgyzstan) using remote sensing data. Global Planet. Change 56, 1-12.

Campbell, J.L., Driscoll, C.T., Pourmokhtarian, A., Hayhoe, K., 2011. Streamflow responses to past and projected future changes in climate at the Hubbard Brook Experimental Forest, New Hampshire, United States. Water Resour. Res. 47, W02514. http://dx.doi.org/10.1029/2010WR009438.

Carter, J.G., Gavan, G., Connelly, A., Guy, S., Handley, J., Kazmierczak, A., 2015. Climate change and the city: Building capacity for urban adaptation. Prog. Plan. 95, 1-66.

Chu, T.W., Shirmohammadi, A., Montas, H., Sadeghi, A., 2004. Evaluation of the SWAT model's sediment and nutrient components in the piedmont physiographic region of Maryland. Trans. ASAE 47 (5), 1523-1538.

FAO, IIASA, ISRIC, ISSCAS, JRC, 2012. Harmonized World Soil Database (Version 1.2). Food \& Agriculture Organization of the UN, Rome, Italy and International Institute for Applied Systems Analysis, Laxenburg, Austria.

Ficklin, D.L., Stewart, I.T., Maurer, E.P., 2013. Effects of projected climate change on the hydrology in the Mono Lake Basin, California. Climatic Change 116, 111 131.

Gan, R., Luo, Y., 2013. Using the nonlinear aquifer storage-discharge relationship to simulate the baseflow of glacier and snowmelt dominated basins in northwest China. Hydrol. Earth Syst. Sci. 17, 3577-3586.

Gassman, P.W., Reyes, M.R., Green, C.H., Arnold, J.G., 2007. The soil and water assessment tool: historical development, applications, and future research directions. Trans. ASABE 50 (4), 1211-1250.

Hagg, W., Mayer, C., Lambrecht, A., Kriegel, D., Azizov, E., 2013. Glacier changes in the Big Naryn basin, Central Tian Shan. Global Planet. Change 110, 40-50.

Immerzeel, W.W., van Beek, L.P., Bierkens, M.F.P., Bierkens, M.F., 2010. Climate change will affect the Asian water towers. Science 328, 1382-1385.

Immerzeel, W.W., Pellicciotti, F., Bierkens, M.F.P., 2013. Rising river flows throughout the twenty-first century in two Himalayan glacierized watersheds. Nat. Geosci., 742-745 http://dx.doi.org/10.1038/NGE01896.

IPCC5, 2013. Summary for policymakers. In: Stocker T.F., Qin D., Plattner G.K., Tignor M., Allen S.K., Boschung J., Nauels A., Xia Y., Bex V., Midgley P.M. (Eds.), Climate Change 2013: The Physical Science Basis. Contribution of Working Group I to the Fifth Assessment Report of the Intergovernmental Panel on Climate Change. Cambridge, United Kingdom and New York, NY, USA: Cambridge University Press. 
Khromova, T.E., Osipova, G.B., Tsvetkov, D.G., Dyurgerov, M.B., Barry, R.G., 2006. Changes in glacier extent in the eastern Pamir, Central Asia, determined from historical data and ASTER imagery. Remote Sens. Environ. 102, 24-32.

Kriegel, D., Mayer, C., Hagg, W., Vorogushyn, S., Duethmann, D., Gafurov, A. Farinotti, D., 2013. Changes in glacierisation, climate and runoff in the second half of the 20th century in the Naryn basin, Central Asia. Global Planet. Change $110,51-61$.

Kutuzov, S., Shahgedanova, M., 2009. Glacier retreat and climatic variability in the eastern Terskey-Alatoo, inner Tien Shan between the middle of the 19th century and beginning of the 21st century. Global Planet. Change 69, 59-70.

Leavesley, G.H., Lichty, R.W., Troutman, B.M., Saindon, L.G., 1983. Precipitation runoff Modeling System: User's Manual. US Geological Survey. Water-Resources Investigations Report 83-4238, p. 207.

Li, B., Zhu, A., Zhang, Y., Pei, T., Qin, C., Zhou, C., 2006. Glacier change over the past four decades in the middle Chinese Tien Shan. J. Glaciol. 52, 425-432.

Liu, S., Ding, Y., Shangguan, D., Zhang, Y., Li, J., Han, H., Wang, J., Xie, C., 2006. Glacier retreat as a result of climate warming and increased precipitation in the Tarim river basin, northwest China. Ann. Glaciol. 43, 91-96.

Liu, L., Luo, Y., He, C.S., Lai, J.B., Li, X.B., 2010. Roles of the combined irrigation, drainage, and storage of the canal network in improving water reuse in the irrigation districts along the lower Yellow River, China. J. Hydrol. 391, 157-174.

Long, A.H., Deng, M.J., Xie, L., et al., 2012. Exploring analysis on the adaptive countermeasures to water resources evolvement under the climate change in Xinjiang and Aral Sea Basin. Arid Land Geogr. 35 (3), 377-387.

Luo, Y., Arnold, J., Allen, P., Chen, X., 2012. Baseflow simulation using SWAT model in an inland river basin in Tianshan Mountain, Northwest China. Hydrol. Earth Syst. Sci. 16, 1259-1267. http://dx.doi.org/10.5194/hess-16-1259-2012.

Luo, Y., Arnoldb, J., Liu, S.Y., et al., 2013. Inclusion of glacier processes for distributed hydrological modeling at basin scale with application to a watershed in Tianshan Mountains, Northwest China. J. Hydrol. 477, 72-85.

Lutz, A.F., Immerzeel, W.W., Shrestha, A.B., Bierkens, M.F.P., 2014. Consistent increase in High Asia's runoff due to increasing glacier melt and precipitation. Nature Clim. Change 4, 587-592.

Moriasi, D.N., Arnold, J.G., Liew, M.W.V., Bingner, R.L., Harmel, R.D., Veith, T.L., 2007 Model evaluation guidelines for systematic quantification of accuracy in watershed simulations. Trans ASABE 50, 885-900.

Narama, C., Shimamura, Y., Nakayama, D., Abdrakhmatov, K., 2006. Recent changes of glacier coverage in the western Terskey-Alatoo range, Kyrgyz Republic, using Corona and Landsat. Ann. Glaciol. 43, 223-229.

Narama, C., Kääb, A., Duishonakunov, M., Abdrakhmatov, K., 2009. Spatial variability of recent glacier area changes in the Tien Shan Mountains, Central Asia, using Corona (1970), Landsat (2000), and ALOS (2007) satellite data. Global Planet. Change 71, 42-54.

Neitsch, S.L., Arnold, J.G., Kiniry, J.R., Williams, J.R., 2005. Soil water assessment tool theoretical document, version 2005. Grassland, Soil and Water Research
Laboratory, Agricultural Research Service, 808 East Blackland Road, Temple, Texas, 76502. http://swat.tamu.edu/documentation.

Niederer, P., Bilenko, V., Ershova, N., Hurni, H., Yerokhin, S., Maselli, D., 2008. Tracing glacier wastage in the Northern Tien Shan (Kyrgyzstan/Central Asia) over the last 40 years. Climatic Change 86, 227-234.

Raper, S.C.B., Braithwaite, R., 2009. Glacier volume response time and its links to climate and topography based on a conceptual model of glacier hypsometry. The Cryosphere 3, 183-194.

Savoskul, O.S.; Smakhtin, V., 2013. Glacier systems and seasonal snow cover in six major Asian river basins: water storage properties under changing climate. Colombo, Sri Lanka: International Water Management Institute (IWMI), (IWMI Research Report 149), p. 69. http://dx.doi.org/10.5337/2013.203.

Schaefer, J.M., Denton, G.H., Barrell, D.J.A., Ivy-Ochs, S., Kubik, P.W., Andersen, B.G., Phillips, F.M., Lowell, T.V., Schluchter, C., 2006. Near-synchronous interhemispheric termination of the last glacial maximum in mid-latitudes. Science 312 (5779), 1510.

Sheffield, J., Goteti, G., Wood, E.F., 2006. Development of a 50-year high-resolution global dataset of meteorological forcings for land surface modeling. J. Climate 19, 3088-3111. http://dx.doi.org/10.1175/JCLI3790.1.

Singh, P., Bengtsson, L., 2005. Impact of warmer climate on melt and evaporation for the rainfed, snowfed and glacierfed basins in the Himalayan region. J. Hydrol. 300, 140-154.

Sorg, A., Bolch, T., Stoffel, M., et al., 2012. Climate change impacts on glaciers and runoff in Tien Shan Central Asia. Nature Clim. Change. http://dx.doi.org/ 10.1038/NCLIMATE1592.

Spruill, C.A., Workman, S.R., Taraba, J.L., 2000. Simulation of daily and monthly stream discharge from small watersheds using the SWAT model. Trans. ASAE 43 (6), 1431-1439.

Tahir, A.A., Chevallier, P., Arnaud, Y., Neppel, L., Ahmad, B., 2011. Modeling snowmelt runoff under climate scenarios in the Hunza River basin, Karakoram Range, Northern Pakistan. J. Hydrol. 409, 104-117.

Taylor, K.E., Stouffer, R.J., Meehl, G.A., 2012. An overview of CMIP5 and the experiment design. Bull. Am. Meteorol. Soc. 93, 485-498.

Unger-Shayesteh, K., Vorogushyn, S., Farinotti, D., Gafurov, A., Duethmann, D., Mandychev, A., Merz, B., 2013a. What do we know about past changes in the water cycle of Central Asian headwaters? A review. Global Planet. Change 110, $4-25$.

Unger-Shayesteh, K., Vorogushyn, S., Merz, B., Frede, H.G., 2013b. Introduction to "Water in Central Asia - Perspectives under global change". Global Planet. Change 110, 1-3.

Yatagai, A., Kamiguchi, K., Arakawa, O., Hamada, A., Yasutomi, N., Kitoh, A., 2012. APHRODITE: Constructing a long-term daily gridded precipitation dataset for Asia based on a dense network of rain gauges. B. Am. Meteorol. Soc. 93, 14011415. http://dx.doi.org/10.1175/BAMS-D-11-00122. 